\title{
ANALISIS DAN PERANCANGAN SISTEM INFORMASI UNDANG- UNDANG WAKAF DALAM TATA KELOLA LEMBAGA PENDIDIKAN ISLAM DAN HASIL BELAJAR
}

\author{
Eddy Saputra ${ }^{1}$, Rayung Wulan ${ }^{2}$ \\ Program Studi Teknik Informatika, Universitas Indraprasta PGRI ${ }^{1,2}$ \\ Email: saputra2578@gmail.com ${ }^{1}$ \\ Email : utha2578@gmail.com ${ }^{2}$
}

\begin{abstract}
Abstrak
Kajian tentang sistem informasi undang undang wakaf bertujuan membangkitkan gairah umat dalam menciptakan sebuah lembaga pendidikan yang berkualitas serta mampu berjalan tanpa memiliki ketergantungan kepada negara ataupun lembaga yang lainya. Sistem informasi undang undang wakaf merupakan sebuah gerakan yang di landasi oleh kesadaran serta ke ikhlasan dari masing-masing orang yang mau menafkahkan sebagian hartanya. Semangat mendonasikan dana dalam bentuk wakaf tidak hanya sekedar untuk menciptakan lembaga pendidikan semata, tetapi sebagai salah satu sarana untuk mendekatkan diri pada Tuhan. Berbeda dengan lembaga pendidikan swasta dimana keuangan sekolah dihasilkan melalui sebuah kewajiban yang harus dibayarkan siswa. Banyak dana yang didapat dari informasi wakaf yang di kelola secara pofesional dan amanah sehingga berpotensi dalam menghasilkanlembaga pendidikan yang berkulitas. Sistem Informasi Lembaga pendidikan yang di kelola melalui dana wakaf memiliki spirit lebih dalam menghasil sumber daya manusia sebagai out put belajar. Kesadaran akan nilai-nilai ketuhanan yang menjadi landasan wakaf membuat pengelolah secara sunguh-sunguh dalam penggunaan keuangan. Berbeda dengan informasi lembaga swasta pada umumnya, dimana tidak sedikit pendidikan masih di jadikan komoditi bisnis, sehingga tidak jarang sebuah lembaga pendidikan hanya mengedepankan gengsi dibandingkan hasil proses pembelajaran dari pendidikan tersebut. Manusia yang cerdas dapat dibangun melalui sebuah proses pembelajan yang serius, tata kelola sebuah lembaga pendidikan harus mengacu pada nilai moral yang diajarkan oleh agama sehingga dapat menghasil sumber daya manusia yang beriman dan bertaqwa.
\end{abstract}

Kata kunci: Perancangan Sistem Informasi, Tata kelola undang undang wakaf, Hasil belajar

\section{Pendahuluan}

Sistem informasi dan dunia pendidikan sudah menjadi satu dalam proses belajar dan pembelajaran. Keduanya membutuhkan biaya yang tidak sedikit dalam proses pembelajaran. Keterbatasan biaya dalam pendidikan dapat menjadi penyebab kegagalan dalam proses belajar mengajar. Wakaf dapat menjadi salah satu sumber pendanaan dalam memajukan pendidikan Islam, yang semakin tertinggal jika dibanding dengan pendidikan barat.

Lembaga wakaf dalam pengembangan pendidikan pada dasarnya sumber keuangan bertumpu pada donasi orang-orang yang mau memberikan sebagian rizkinya, berbeda dengan lembaga pendidikan non. Dengan adanya sistem informasi dan undang undang wakaf dimana sumber keuangan diambil dari sistem informasi yang didapat dari siswa dan ada beberapa subsidi dari pemerintah. Tata kelola dalam lembaga pendidikan dapat mengarahkan serta menentukan hasil yang akan di capai. Pendidikan Islam yang lebih mengedepankan akhlak dan moral diperlukan sebuah proses pembelajaran secara berkala dan berkesinambungan, dikarenakan laju perkembangan sistem informasi oleh sebab itu pendidikan dalam Islam jangan sampai terhenti hanya karena terkendala faktor pembiayaan.

Peranan sistem informasi undang undang wakaf sangat besar untuk menunjang keberlangsungan pendidikan Islam dalam melaksakan pendidikan. Melalui gerakan informasi wakaf umat Islam dimana pun mendapatkan kemudahan dalam menuntut ilmu. 
Karena informasi wakaf dalam menjalankan proses pendidikan tidak banyak menuntut biaya dari pelajar, sehingga mereka dapat fokus belajar sehingga tidak ada perbedaan antara si miskin dan kaya dikarenakan semua mendapatkan kesempatan belajar yang sama. Untuk itulah tidak ada salahnya jika lembaga pendidikan di Indonesia mengikuti jejak Universitas Al-Azhar dalam mengelola lembaga pendidikannya secara berdasarkan informasi undang undang wakaf,agar lembaga pendidikannya bisa menjadi lembaga pendidikan yang mandiri dan tidak tergantung dengan subsidi pemerintah saja. Selain itu, wakaf di Universitas AlAzhar mampu membuatnya bertahan hingga saat ini.

Pemerintah dalam tata kelola lembaga pendidikan masih sering terkendala oleh aturan-aturan yang dengan mudah serta spontan berubah-ubah. Pergantian pejabat dalam struktrur di lembaga pendidikan dapat berpengaruh pada kebijakan,dimana tanpa disadari dapat mengubah tujuan dari proses belajar mengajar. Panjangnya birokrasi banyaknya regulasi belum lagi kebijakan politis,itu hanya beberapa prosudural yang harus di tempuh dan dilalui.

Sistem informasi adalah suatu sistem yang memiliki kemampuan untuk mengumpulkan informasi dari semua sumber dan menggunakan berbagai media untuk menampilkan informasi.

Pemanfaatan hasil informasi berdasarkan undang undang wakaf yang paling banyak pengaruhnya diantaranya adalah tata kelola wakaf untuk pengembangan pendidikan. Sedangkan lembaga pendidikan yang telah menerapkan model pengelolaan ini antara lain adalah al-Azhar. Al-Azhar merupakan lembaga pendidikan yang mampu membiayai operasional pendidikannya tanpa bergantung pada pemerintah maupun pembayaran siswa dan mahasiswanya. Idealnya ini dapat dilakukan di Indonesia yang dimana jumlah umat Islam di negeri ini mayoritas muslim.

Perangkat undang-undang yang ada di negara kita telah memfasilitasi bagaimana mekanisme perwakafan. Ada beberapa lembaga pendidikan yang ada di Indonesia yang sudah menerapkan lembaga pendidikannya melalui lembaga wakaf. Badan wakaf pondok modern Gontor, Badan wakaf Universitas Islam Indonesia Jogyakarta, Badan wakaf Universitas Muslim Indonesia Makasar dan masih banyak lembaga pendidikan lainnya.

\section{Tinjauan Pustaka}

Sistem Informasi merupakan seperangkat komponen yang saling berhubungan, dan yang berfungsi mengumpulkan, memproses, menyimpan dan mendistribusikan informasi untuk mendukung pembuatan keputusan dan pengawasan dalam organisasi.

Informasi adalah berita terutama fakta dan data yang sudah diproses sehingga memiliki arah tertentu yang dapat dimanfaatkan misalkan dalam pengambilan keputusan oleh manajer Pidarta, 2011:148).

Informasi adalah hasil dari pengolahan data dalam suatu bentuk yang lebih berguna dan lebih berarti bagi penerimanya yang menggambarkan suatu kejadian-kejadian (event) yang nyata (fact) yang digunakan untuk pengambilan keputusan (Jogiyanto ,2009: 192)

Suatu sistem dapat terdiri dari sistem-sistem bagian (subsistem) yang saling berinteraksi, sebagai akibat adanya input yang diproses menjadi output / informasi, misalnya sebuah komputer terdiri dari beberapa komponen.

Idealnya , tiap-tiap lembaga pendidikan memiliki Sistem Informasi yang merupakan unit/sub unit atau badan tersendiri lengkap dengan susunan petugasnya. Namun bila kondisi belum memungkinkan, misalnya karena belum ada sarana, belum disediakan biaya, atau belum cukup paham akan pekerjaan badan itu maka ia bisa ditangani secara rangkap dalam satu sistem informasi oleh pejabat tertentu yang menangani urusan kerumahtanggaan lembaga (Pidarta, 2011:153). 
Salah satu pranata sosial dalam Islam yang mempunyai nilai sosial dan ekonomi adalah lembaga perwakafan, sebagai kelanjutan dari nilai-nilai ke Tuhanan. Lembaga perwakafan adalah salah satu bentuk perwujudan keadilan sosial dalam Islam. Sebuah prinsip dalam Islam bahwa kepemilikan harta tidak dibenarkan di miliki oleh sekelompok orang. Islam memiliki konsep dari harta yang dimiliki ada sebagian hak dari orang.

Dalam kaitannya dengan Islam, sistem Informasi mungkin akan lebih mengarah kepada informasi tentang adanya undang undang wakaf dalam sistem yang. Pers Islam dalam pertumbuhan dan perkembangannya dapat dilihat dalam dua bentuk, yaitu pers Islam yang menampilkan Islam sebagai rubrik, dan pers Islam yang menonjolkan Islam sebagai nafas, semangat, dan komitmen (Sudirman Tebba, 2001:173)

Peraturan perundang-undangan tentang wakaf yang ada di Indonesia sudah ada jauh sebelum Indonesia merdeka. Namun, peraturan-peraturan tersebut waktu itu belum cukup memadai dari sisi kandungan pengaturannya maupun jenis peraturannya. Maksudnya, pengaturan yang ada pada masa lalu, peraturan-peraturan itu masih sederhana dan tidak mencakup segala aspek dari wakaf itu sendiri. Kemudian dari aspek legalitasnya, peraturan tentang wakaf pada masa lalu belum ada yang setingkat undang-undang.

Hukum perwakafan mendapatkan perhatian yang layak di indonesia, meskipun dari segi sumber ajaran Islam, wakaf tidak terdapat penjelasan secara eksplisit didalam Al Qur'an. Dalam hal ini umat Islam berkeyakinan wakaf merupakan bagian dari sedekah. Peraturan perundang-undang tentang perwakafan produk sudah ada sejak pemerintah Belanda.

Perkembangan ilmu pengetahuan semakin pesat, salah satu upaya strategis untuk meningkatkan kualitas pendidikan melalui gerakan pemberdayaan umat dengan tata kelola wakaf sehingga mampu menghasilkan pelajar-pelajar yang sungguh-sungguh dalam menjalankan aktifitas belajar mengajar tanpa terkendala dengan biaya, disamping wakaf dapat berperan untuk meningkatkan kesejahteraan para guru dan dosen, meningkatkan kualitas pendidikan melalui perbaikan kurikulum, manajemen pendidikan, serta meningkatkan peran serta masyarakat dalam penyelenggaan pendidikan.

Sistem informasi adalah suatu kombinasi terartur apapun dari people (orang), hardware (perangkat keras), software (piranti lunak), computer networks and data communications (jaringan komunikasi), dan database (basis data) yang mengumpulkan, mengubah dan menyebarkan informasi di dalam suatu bentuk organisasi. (O’Brien 2005 :5).

Menurut (Abdurrahman Kasdi:2106) informasi Wakaf dan pendidikan berputar dalam satu lingkaran, masing-masingdipengaruhi oleh yang sebelumnya dan mempengaruhi yangsesudahnya. Ketika banyak orang yang berwakaf untuk pendidikan,maka makmurlah lembaga-lembaga pendidikan dan lembaga riset yang selanjutnya menghasilkan banyak orang-orang pandai yang nantinyajuga akan mengeluarkan wakaf. Sebaliknya, di zaman kemundurantidak banyak orang yang mengeluarkan wakaf untuk pendidikan,yang menyebabkan kemunduran lembaga-lembaga pendidikan danlembaga riset, selanjutnya membawa kurangnya orang-orang pandaidi kalangan Islam sendiri yang mampu mengeluarkan wakaf. Makadari itu, jalinan antara wakaf dan pendidikan sangat diperlukan untukmendukung mata rantai kebangkitan pendidikan Islam.

Mekanisme tata kelola wakaf yang paling utama dan awal adalah menghimpun harta benda wakaf dari para wakif. Penghimpunan (Fundraising) adalah sebuah kegiatan pengumpulan dana dari individu, organisasi, maupun badan hukum. Fundraising juga merupakan proses mengajak masyarakat atau calon wakif agar mau melakukan amal kebajikan dalam bentuk pemberian hartanya untuk diwakafkan.

Adapun tujuan fundraising menurut Juwaini dalam (Miftahul Huda:2014) diantaranya yaitu sebagai tujuan yang paling mendasar. Dana yang dimaksudkan adalah dana maupun daya operasi pengelolaan lembaga. Tujuan inilah yang paling pertama dan utama dalam 
pengelolaan lembaga dan ini pula yang menyebabkan mengapa dalam pengelolaan fundraising harus dilakukan. Selain itu tujuan fundraising adalah menambah donatur atau menambah populasi donatur.

Dalam institusi pendidikan Islam, kita tidak dapat melepaskan peran wakaf yang sangat berpengaruh terhadap kelangsungan kegiatan pendidikan. Seperti yang telah kita ketahui bahwa, dalam institusi pendidikan dapat kita katakan mendapat dukungan dari wakaf, sebagai titik awal berdirinya sebuah sarana pendidikan. Awal berdirinya an-Nashiriyah dan al-Azhar tidak terlepas dari wakaf sebagai faktor pendukung berdirinya.

Menurut (Azyumardi Azra, 2001) Pesantren dapat dikatakan induk institusi pendidikan Islam di Indonesia, namun definisi pesantren masih mengalami beberapa perbedaan dalam memberikan definisi. Lembaga pendidikan pesantren berkembang pesat di Indonesia, dan pada akhirnya pesantren menjadi ciri khusus yang mengandung makna keaslian Indonesia (indigeneous). Karena pesantren merupakan lembaga pendidikan yang menekankan pada kesederhanaan hidup disamping materi yang lain.

Sehingga semakin hari santri semakin banyak. Kemungkinan yang sangat berpengaruh adalah murahnya biaya pendidikan. Secara geografis pesantren pada awal perkembangannya terletak di pedesaan, dan anggapan yang timbul bila kita mengingat pedesaan adalah murahnya biaya hidup. Para santri tidak pernah membayar uang sekolah dan semacamnya untuk pendidikan yang mereka terima. Begitu pula mereka tidak dipungut biaya untuk membayar sewa kamar (asrama). Sebab pesantren telah mendapatkannya dari wakaf.

Didin Hafidhuddin dalam bukunya yang berjudul Islam Aplikatif menerangkan sumbersumber informasi wakaf tidak hanya digunakan untuk membangun perpustakaan, ruangruang belajar, tetapi juga untuk membangun perumahan siswa, kegiatan riset, seperti untuk jasa-jasa fotokopi, pusat seni, dan lain-lain.Dalam usahanya untuk memotivasi riset, program penerjemahan juga ditunjang hasil-hasil wakaf. Banyak sekali buku yang ditulis atau diterjemahkan oleh sarjana dan ilmuwan Muslim didanai oleh wakaf.Riset-riset baik yang menggunakan metode empiris maupun sainstifik terus dikembangkan dan didukung pendanaannya oleh wakaf.

\section{Metodologi penelitian}

Pendekatan yang dilakukan adalah melalui pendekatan kualitatif. Artinya data yang dikumpulkan bukan berupa angka-angka, melainkan data tersebut berasal dari naskah wawancara, catatan lapangan, dokumen pribadi, pengamatan, dan catatan resmi lainya berdasarkan sistem informasi yang didapat, sehingga yang menjadi tujuan dari penelitian kualitatif ini adalah ingin menggambarkan realita empirik dibalik fenomena secara mendalam, rinci dan tuntas. Oleh karena itu penggunaan pendekatan kualitatif dalam penelitian ini adalah dengan mencocokan antara realita empirik dengan teori yang berlaku dengan menggunakan metodologi kualitatif deskriftif ( Lexy J moleong 2013 ).

Metode kualitatif adalah metode penelitian yang digunakan untuk meneliti pada kondisi obyek yang alamiah, di mana peneliti sebagai instrument kunci, teknik pengumpulan data dilakukan secara gabungan, analisis data yang bersifat induktif, dan hasil penelitian kualitatif lebih menekankan makna dari pada generalisasi. Menurut ( Mukhtar 2013 ), penelitian kulalitatif deskriftif adalah suatu metode yang digunakan untuk menemukan pengetahuan terhadap subyek penelitian pada suatu saat tertentu, kata deskriptif berasal dari bahasa latin “deskriptivus' yang berarti uraian.

Peneliti menggambarkan bentuk dan alur dari penelitian tersebut. 


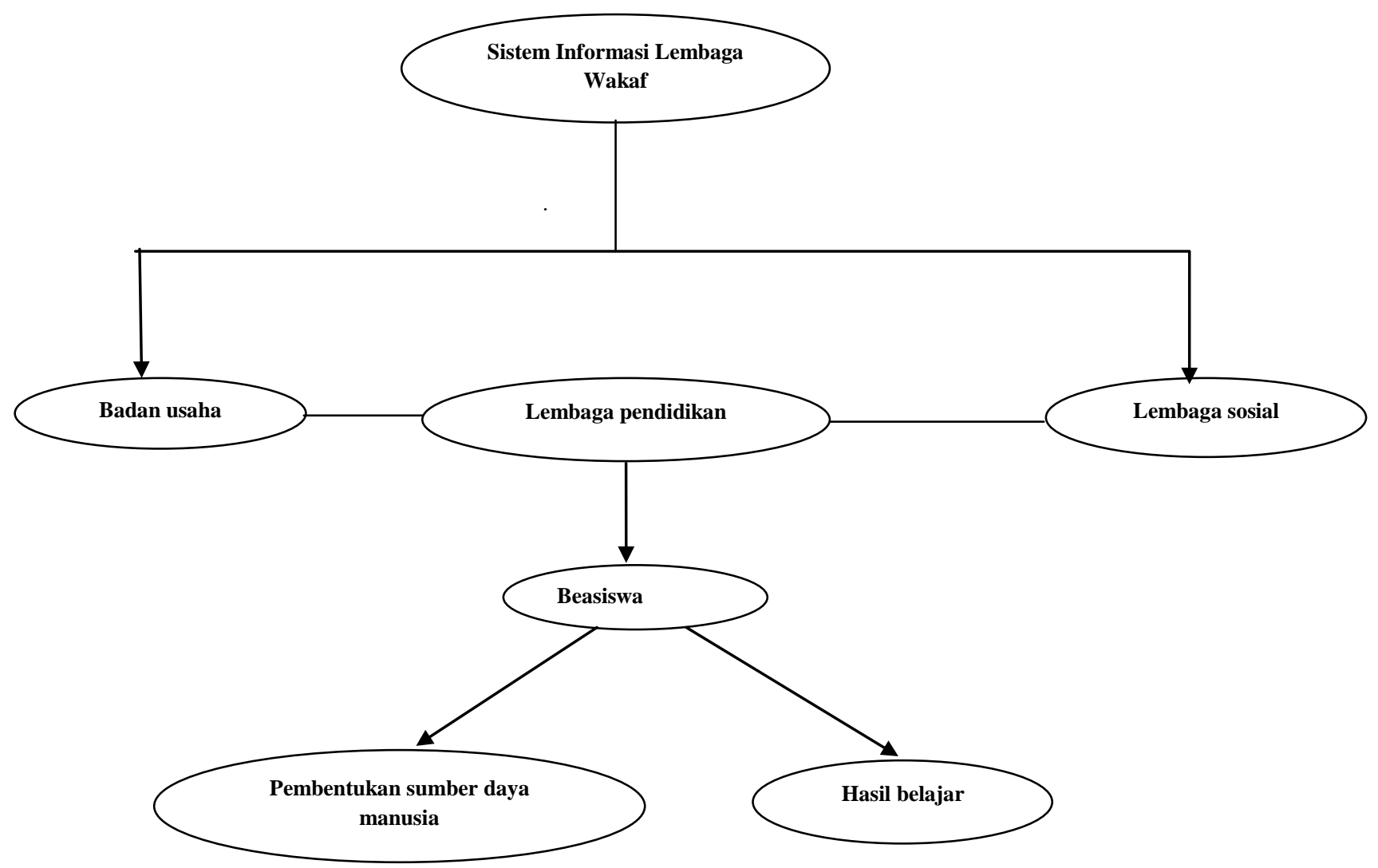

Gambar 1. Model Wakaf Terpadu

Sumber (Lexy J moleong 2013)

\section{Hasil dan Pembahasan}

\section{Analisis Perancangan Sistem undang undang Wakaf}

Perancangan merupakan suatu kegiatan yang memiliki tujuan untuk mendesain sistem baru yang dapat menyelesaikan masalah-masalah yang dihadapi suatu organisasi yang diperoleh dari pemilihan alternative untuk mendapatkan sistem yang terbaik.

Sistem Informasi Undang-undang perwakafan yang ada saat ini, di jaman modern memberikan ruang bagi setiap lembaga pendidikan dalam mengembangan lembaga tersebut . Rancangan website Sistem informasi tata kelola wakaf pembuat website masih banyak menggunakan CSS (Casyading Style Shet) yang berfungsi untuk mengatur format/tampilan suatu halaman HTML agar mudah dalam mengelola tampilan suatu website.Didalam pembuatan aplikasi memakan waktu yang cukup lama dalam proses pengkodean membuat fungsi-fungsi tersebut dan dengan pengkodean tiap class atau fungsi yang diatur oleh si pembuat web dalam hal ini proses CRUD (Create, Read, Update, Delete) informasi menjadi terhambat dikarenakan struktur file tidak memiliki aturan yang baku, dan tentu saja 
hal ini akan menyebabkan proses CRUD ( Create, Read, Update, Delete ) situs akan menjadi lambat. Jadi diperlukan Framework sebagai alat bantu untuk membuat web .

Membangun suatu sistem informasi memerlukan pemahaman yang baik dan jelas mengenai sistem yang akan digunakan baik dalam prosedur sistem,input,output maupun hal-hal yang mempengaruhi kinerja sistem baik untuk jangka pendek maupun jangka panjang.

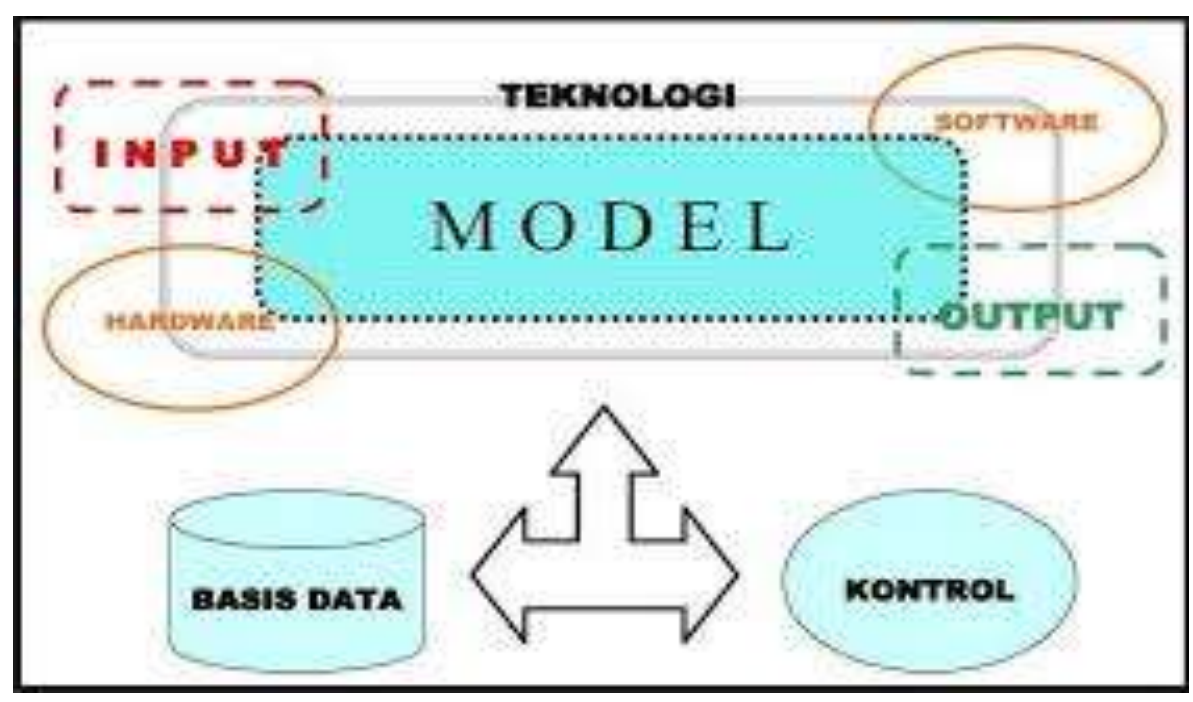

Gambar 2. Kerangka framework Sistem Informasi Sumber (Pidarta, 2011)

Basis data digunakan untuk menguraikan segala sesuatu dari sekumpulan data tunggal, seperti daftar telepon. Basisdata terdiri dari file-file fisik yang ditetapkan berdasarkan komputer saat menerapkan perangkat lunak basisdata. Sebuah basisdata adalah tempat penyimpanan file data. Sebagai file data, suatu basisdata tidak menyajikan informasi secara langsung kepada pengguna. Pengguna harus menjalankan aplikasi untuk mengakses data dari basisdata dan menyajikannya dalam bentuk yang bisa dimengerti.

Rancangan merupakan strategi atau suatu kegiatan yang bertujuan untuk mendesain sistem baru yang dapat memecahkan masalah yang dihadapi untuk menmenghasilkan tampilan desain yang sesuai dengan kriteria.

Rancangan antar muka merupakan bentuk tampilan yang dirancang untuk sistemyang dibuat. Rancangan menu utama terdiri dari 6(enam) menu bar. Masing-masing menu bar memuat beberapa frame yang memiliki fungsi masing-masing. Jika masing-masing menu bar disorot atau menu item diklik maka akan tampil frame baru.

Berikut tampilan rancangan antar muka yang akan di buat sesuai dengan kebutuhan untuk tata kelola wakaf. 


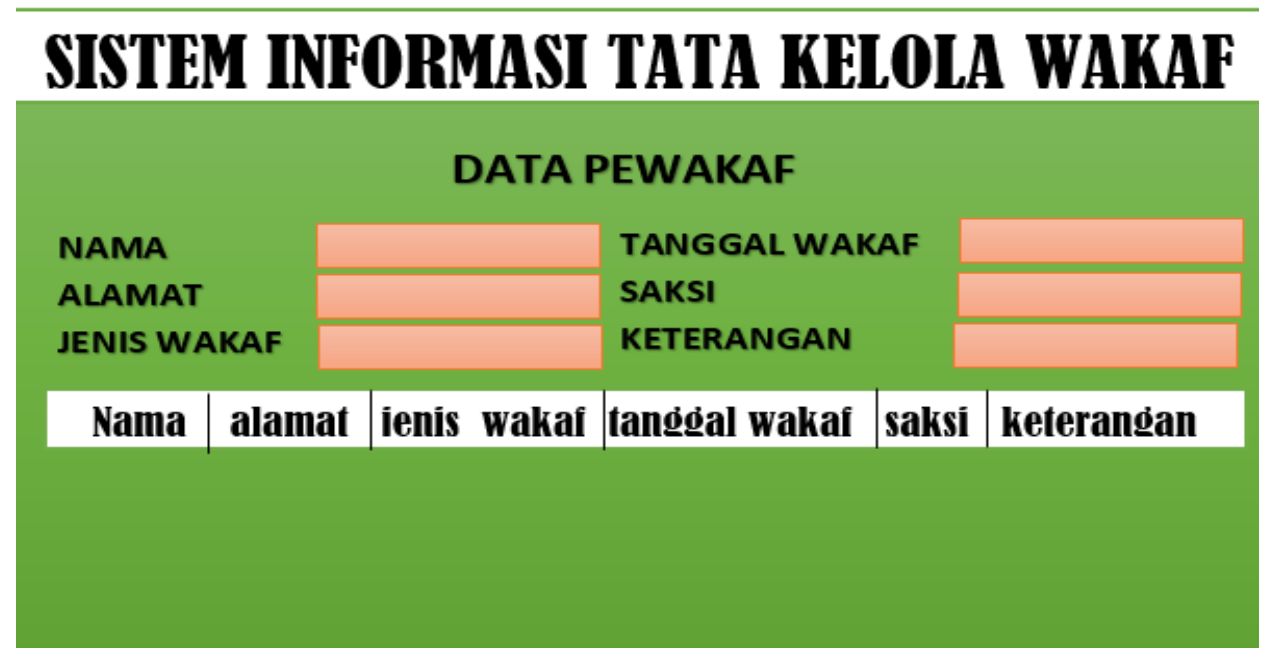

Gambar 3. Rancangan Antar Muka

Sumber: (Rancangan Penulis 2016)

Rancangan input data merupakan hasil input yang didapat oleh admin yang dirancang untuk sistem input masukan yang dibuat. Rancangan input data terdiri dari 6(enam) menu bar. Masing-masing menu bar memuat beberapa frame yang memiliki fungsi masing-masing. Jika masing-masing menu bar disorot atau menu item diklik maka akan tampil frame baru. Berikut tampilan rancangan antar muka

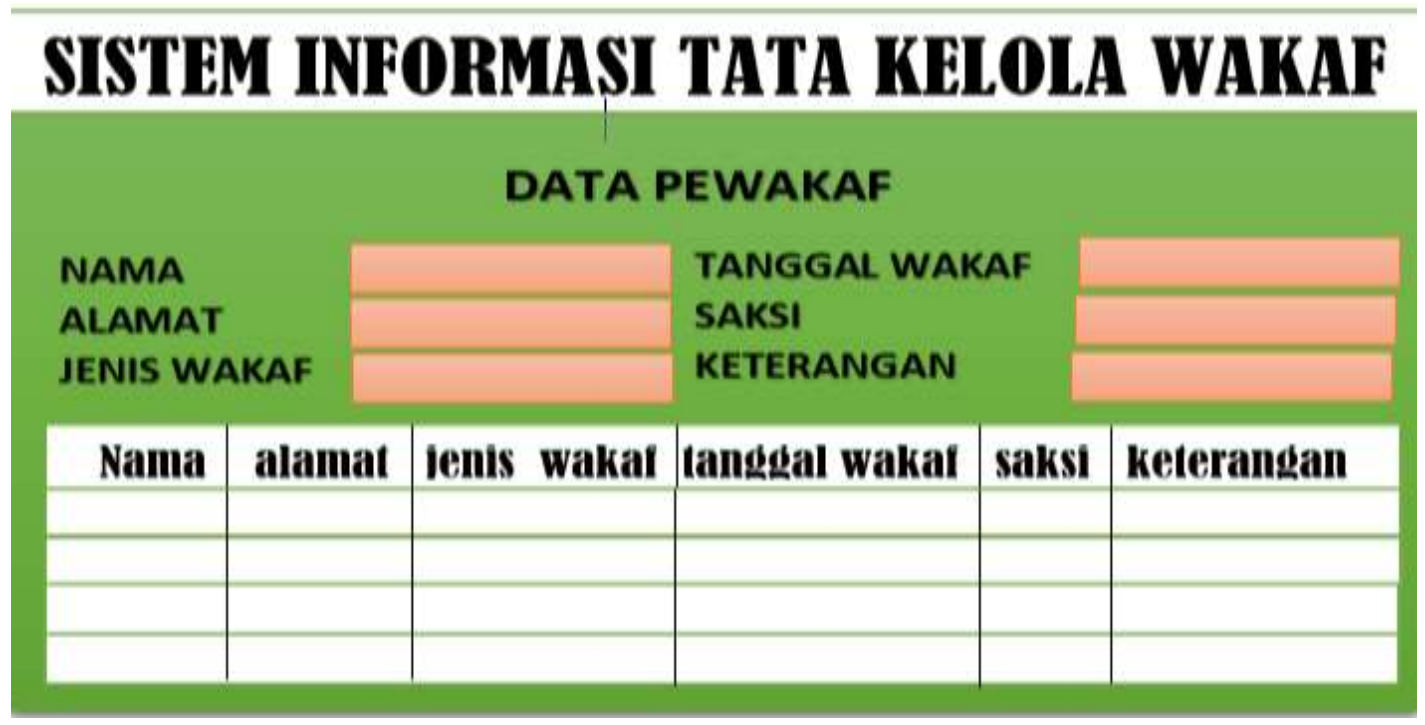

Gambar 4. Rancangan input data

Sumber: (Rancangan Penulis 2016) 


\section{Analisis Sistem Informasi Tata kelola Wakaf}

Merancang sistem aplikasi dibutuhkan tahapan pada langkah-langkah pembuatan sistem, tahapan perancangan memiliki tujuan untuk mendesain sistem baru yang dapat menyelesaikan masalah-masalah yang dihadapi oleh perusahaan untuk memilih alternatifalternatif terbaik pada sistem. Sementara itu, sistem adalah sekumpulan prosedur atau komponen yang saling berkaitan dan mendukung satu sama lain serta beroperasi untuk mencapai tujuan tertentu.

Rancangan layar Sistem informasi Undang-undang Wakaf salah satu cara untuk mengatasi masalah-informasi yang kurang akurat, dengan informasi yang akurat tersebut, dapat dilakukan dengan menggunakan Framework sebagai suatu solusi dalam memberikan kemudahan dalam pengelolaan website.

Sistem informasi tata kelola wakaf yang diusulkan menggunakan framework Codeigniter dengan konsep MVC yang memisahkan logika dan tampilan sehingga pekerjaan lebih mudah dengan memilah dan framework bootstrap sebagai CSS karena banyak situs-situs web yang lebih mengedepankan penyajian informasi. Dengan framework ini para pengguna informasi ini tidak lagi kesulitan dalam mendapatkan informasi yang up to date tentang tata kelola wakaf secara online yang dapat dijalankan di berbagai macam perangkat seperti Notebook, PC, dan diberbagai macam sistem operasi .

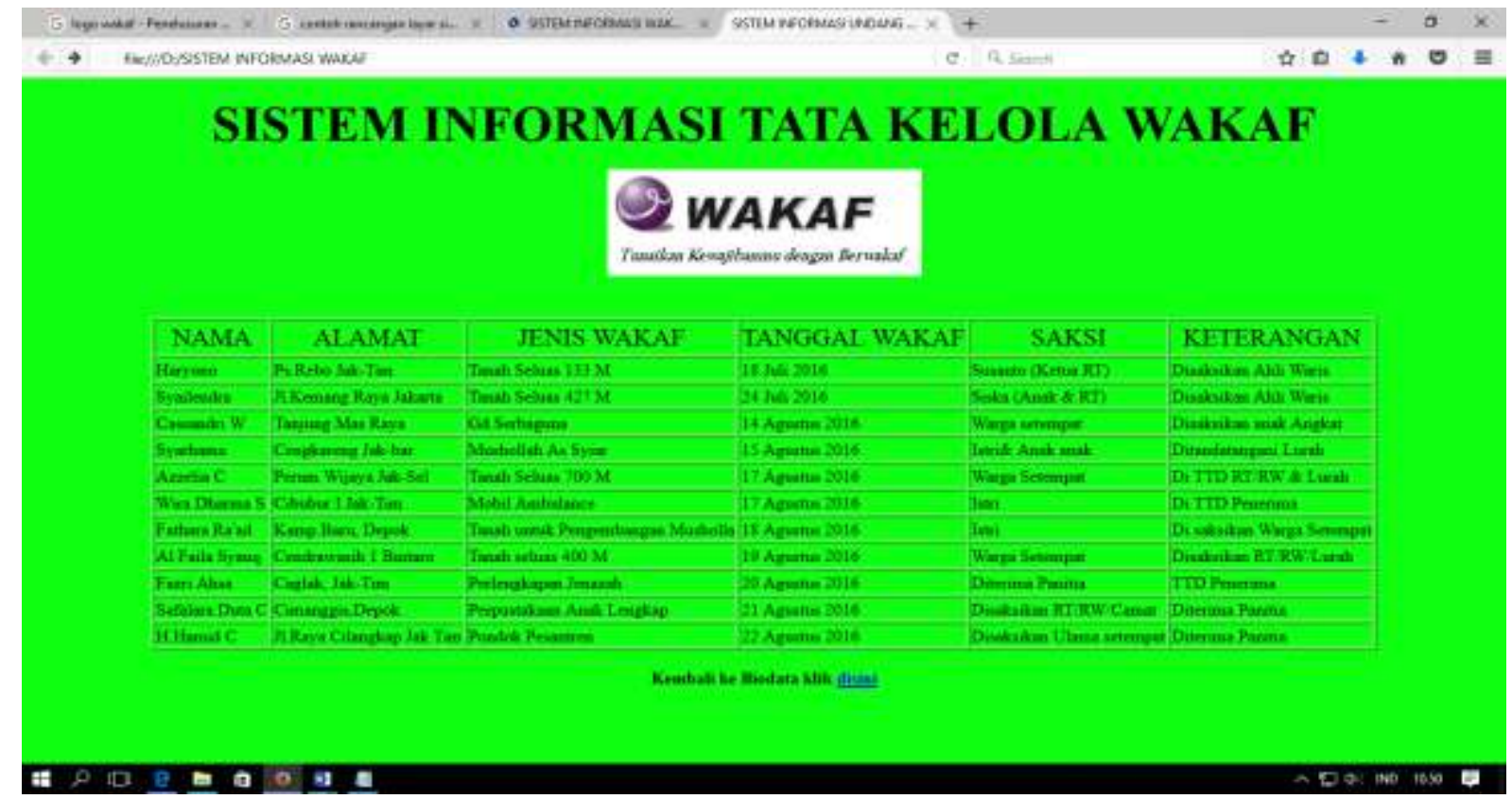

Gambar 5. Rancangan Layar Utama

Sumber: (Rancangan Penulis 2016)

Keberhasilan lembaga pendidikan yang kelola oleh beberapalembaga besar yang ada membuktikan jika sistem informasi tata kelola wakaf mampu menjadi garda terdepan dalam menciptakan lembaga pendidikan yang unggul serta mampu melahirkan sumber daya manusia dengan implementasi hasil belajar yang di terapkan dalam kehidupan sehari-hari. Sistem informasi ini merupakan sebagian kecil di karenakan aspek penelitian ini lebih 
kepada analisis undang-undang perwakafan dalam tata kelola lembaga pendidikan dalam menghasilkan sumber daya manusia serta kualitas dari hasil proses belajar.

\section{Simpulan dan Saran}

\section{Simpulan}

1. Berdasarkan analisis yang di uaraikan di atas, Sistem informasi tata kelola wakaf yang ada di Indonesia memiliki keberpihakan dalam terbentuknya lembaga pendidikan melalui tata kelola wakaf.

2. Melalui lembaga pendidikan berbadan wakaf siapapun dapat belajar dengan sunguhsungguh tanpa harus terkendala oleh biaya, sehingga para siswa terdorong untuk mempertahankan beasiswa hingga selesai yang berdampak pada hasil belajar.

3. Keberadaaan sistem informasi tata kelola wakaf memiliki lembaga pendidikan yang bisa jadi alternatif untuk menghasilkan lembaga pendidikan yang berkualitas di tengah laju sistem informasi dalam dunia pendidikan.

\section{Saran}

1. Di butuhkan Peraturan pemerintah yang jelas dan dituangkan dalam undang undang tentang tata kelola wakaf.

2. Sistem informasi tata kelola wakaf hendaknya memiliki jaringan yang luas sehingga lembaga lembaga pendidikan dapat dengan mudah menginformasikan

3. Dalam mengelola Sistem informasi dibutuhkan kerjasama antara lembaga tata kelola wakaf dan instasi pemerintah.

\section{Daftar Pustaka}

Jogiyanto, H.M. (2009). Perancangan Sistem Informasi dan Teknologi Informasi. Jakarta

O’Brien .(2005).Analisa dan Desain Sistem Informasi. Jakarta: Gramedia

Kasdi, A. (2016). Jurnal pendidikan Islam, Vol.11 No 1 STIAN Kudus

Azyumardi Azra. (2001). Sejarah Pertumbuhan dan Perkembangan Lembaga-lembaga Pendidikan Islam di Indonesia. Jakarta: Grasindo

Miftahul Huda. (2014) Mengalirkan Manfaat Wakaf Potret Perkembangan Hukum dan Tatakelola Wakaf di Indonesia . Ponorogo: STAIN Press.

Moleong J lexy. (2013). Metode Penelitian Kualitatif. Edisi Revisi. Cetakan ke 13.

Bandung: Remaja Rosdakarya

Muhammad Daud Ali. (2012). Sistem Ekonomi Islam Zakat dan Wakaf. Jakarta: UI press

Republika.co.id, wakaf pesantren Gontor mencapai Milyaran rupiah, 2013

Siah Khosyiah, (2010). Wakaf dan Hibah Bandung: Pustaka Setia

Suroso Abdussalam, (2011). Arah dan Asas Pendidikan Islam, Jakarta: Sukses Publishing 